Bulletin of Taras Shevchenko National University of Kyiv. Public Administration, 2(14), 10-13.

UDC 351.353

DOI: https://doi.org/10.17721/2616-9193.2021/14-2/6

Anar Zeynalov, PhD Student Taras Shevchenko National University of Kyiv, Kyiv, Ukraine e-mail: 2393123@ukr.net

\title{
ORGANIZATIONAL CITIZENSHIP BEHAVIOR IN AZERBAIJAN: THE CASE OF ASAN SERVICE
}

\begin{abstract}
ASAN Service - An affiliation of the State Agency for Public Service and Social Innovations under the President of the Republic of Azerbaijan, has been established in 2012, where different government agencies as well as private companies are able to directly implement their services to the citizens of Azerbaijan. In other words, the government agencies are required to increase the quality of their work, which is based on transparent and equal standards that purely for the benefits of citizens.

However, there are very few studies that investigate what are the main driving forces that motivate citizens to use public services through ASAN Service, while at the same time, it is necessary to understand how the organizational citizenship behavior is formed in this context. This chapter of the research sheds a light on ASAN Service model in Azerbaijan, while at the same time brings the organizational citizenship behavior to the agenda of public sector in the country.
\end{abstract}

Keywords: organizational citizenship behaviour, public service, ASAN Service, Azerbaijan.

\section{Introduction}

The need for daily access to public services by citizens across the world emerged the diffusion of information communication technologies (ICTs) by national governments in order to provide effective and efficient public services. Kurfali et al. (2017) emphasized that public services are among the service areas that are considerably improved due to the broad adoption of ICTs in diverse functions of them. In addition, ICT's adoption positively led to the formation of the concept of e-government, where in technical context, e-government helps to enhance the transactions between service providers and service users (Jaeger, 2003). According to Aggelidid and Chatzoglou (2008), e-government contributes to transparency, accountability, better governance, while at the same time makes the government agencies more result-oriented, and enables citizens and other service users to effectively and efficiently use public services through various communication channels.

ASAN Service is considered Azerbaijani model of public service delivery mechanism in order to "ensure the realization of the services to be rendered by the state entities in a uniformed and coordinated manner."1 It operates through its service centers that located across the regions of Azerbaijan, which are set to provide effective and timely services to citizens and enhance the productivity in public operations. Besides citizens behavior towards public service, it is necessary to understand how organizational citizenship behavior (OCB) is formed within the ASAN Service, and how it influences the functionality of the successful public service model.

Over the past two decades, organizational citizenship behavior (OCB) has been studied as a type of prosocial or voluntary behavior that organizational members engage in to maintain the social context that supports task performance (Organ et al., 2006; Organ, 1997). Examples of public sector employees' citizenship behaviors include helping coworkers with their job tasks; proactively being involved in solving citizens' problems; being actively engaged in identifying problems related to cur- rent public service provision and suggesting appropriate solutions; and helping one's agency to maintain a favorable image in the community. Perry (2000) pointed out that motivational theories based on individuals' self-interest are limited in explaining public workers' prosocial behaviors, noting that traditional motivation studies have been silent on public employees'

\footnotetext{
${ }^{1}$ http://asan.gov.az/en/content/index/145/haqqimizda\#.WC6vbGt94dU.
}

intrinsic motivation to help others, as well as on their sense of moral obligation to engage in prosocial behaviors.

Drawing from the discussion above, this chapter of the research integrates the concept of OCB with ASAN Service model in Azerbaijan, where the prospective studies could theoretically and practically investigate the driving factors of public service-to-citizen behavior, through which policymakers could develop a guideline to enhance the effectiveness of services through increased employee motivation and moral obligation.

\section{"ASAN" Service in Azerbaijan}

The need for daily access to public services by populations all over the world emerged the diffusion of information communication technologies (ICT) by the governments to provide effective and efficient services. Kurfali et al. (2017) reported that public services are one of the service areas that have been significantly improved because of the wide adoption of ICT in them. And, further added that using ICT to increase the public service efficiency constitutes the e-government concept. In the technical context, e-government helps to simplify transactions between service providers and users. According to Aggelidid and Chatzoglou (2008), egovernment enhances accountability, transparency and better governance, makes government result-oriented, while also enable citizens and business units to use government services and related information effectively and efficiently via Internet and other communication channels. Furthermore, it facilitates information and service delivery to citizens, increases productivity among public service providers, and fosters citizen participation (Kim et al., 2009a, 2009b). Kurfali et al. (2017) highlighted that there are numerous adoption theories and models that explain the acceptance of e-government services, and majority of them combined existing models or extended them with the inclusion of new variables (Rokhman, 2011; Sang et al., 2009; Colesca \& Dobrica, 2008). However, there is no prior study examining what factors influence the behavioral intention (BI) to use the public e-services in Azerbaijan in the context of ASAN Service model, since it was launched in 2012. It is the Azerbaijani model of government service delivery mechanism "to ensure the realization of the services to be rendered by the state entities in a uniformed and coordinated manner." In other words, ASAN Service operates through its centers in various locations across the country in order to provide effective service to citizens, increase transparency and 
productivity in government operations, by using modern technological innovations. ASAN Service also provides internet and mobile services to the citizens. ASAN Service established a corruption-free platform to increase the confidence to the state bodies. The Monitoring Report on Azerbaijan (OECD 2013), indicated that the establishment of ASAN Service Centers as well as the electronic services and facilitation of access to public services, adoption of implementation of international anti-corruption standards to national level has increase the reputation of the country. (VISION - The Think-Tank, 2015) proposed that the ASAN Service model is very successful and innovative in delivering public services, compared to other traditional methods in EU states.

Former president of Azerbaijan Republic, Heydar Aliyev approved "National Strategy for information and communications technologies for the development of Azerbaijan Republic" in 2003 to urge the government to launch e-government, which was further intensified by the next president Ilham Aliyev. The major aim was to build healthy bonds between governmental bodies and citizens to increase transparency and responsibility of government officials. The two state programs, namely "State Program on development of communication and information technologies in Azerbaijan Republic in 2005-2008" and the second State Program Electronic Azerbaijan (2010-2012) accelerated the e-government adoption.

According to the e-government development index (EGDI) as well as e-participation index (EPART), Azerbaijan ranks 56th and 47th respectively in 2016. However, in 2014, the rankings scores were 68th and 77th accordingly. These statistics show that Azerbaijan citizens become more frequent internet users, particularly their needs for government services online. Based on the United
Nations E-Government Survey (2016), the United Kingdom is leading on the e-participation index globally, whereas Japan and Australia rank second. It is the fact that Azerbaijan is among the Top 50 performances in eparticipation. The report also listed the countries that are grouped based on the level of Online Service Index (OSI), in which Azerbaijan belongs to High OSI. OSI is related to the electronic and mobile public service delivery in the context of e-government. Finally, in terms of EGDI, Azerbaijan belongs to High-EGDI, which is good indicator for the country. In terms of Telecommunications Infrastructure Index, $61 \%$ of population are internet users, and there are 110.91 mobile cellular telephone subscriptions per 100 inhabitants. The statistical facts indicate that there is very good condition for developing government e-services, especially in online settings in order to simplify the citizen-government interaction and increase the efficiency and effectiveness of the services.

Since its establishment in 2012, ASAN Service has received 37,209,636 applications in general ${ }^{2}$. It shows how successful ASAN Service has been in very short period of time. By considering the population number of Azerbaijan (more than 9.5 million), it can be said that every citizen has used ASAN Service in his/her lifetime. Other infographics show that during the period of 2013-2019, 2,500 visitors visited the official website of ASAN Service daily, more than half a million people liked its Facebook page. In addition, citizens post their questions and requests on its Facebook page, and find solutions very shortly. Since February 4, 2013 , ASAN Service received $78 \%$ of requests by calls, $14 \%$ by Facebook, $7 \%$ online, and $1 \%$ by others. ASAN Service is unique due to the fact that it provides the different public services in a single place implemented by the State Agency. Currently, it serves all across the country (see Fig. 1).

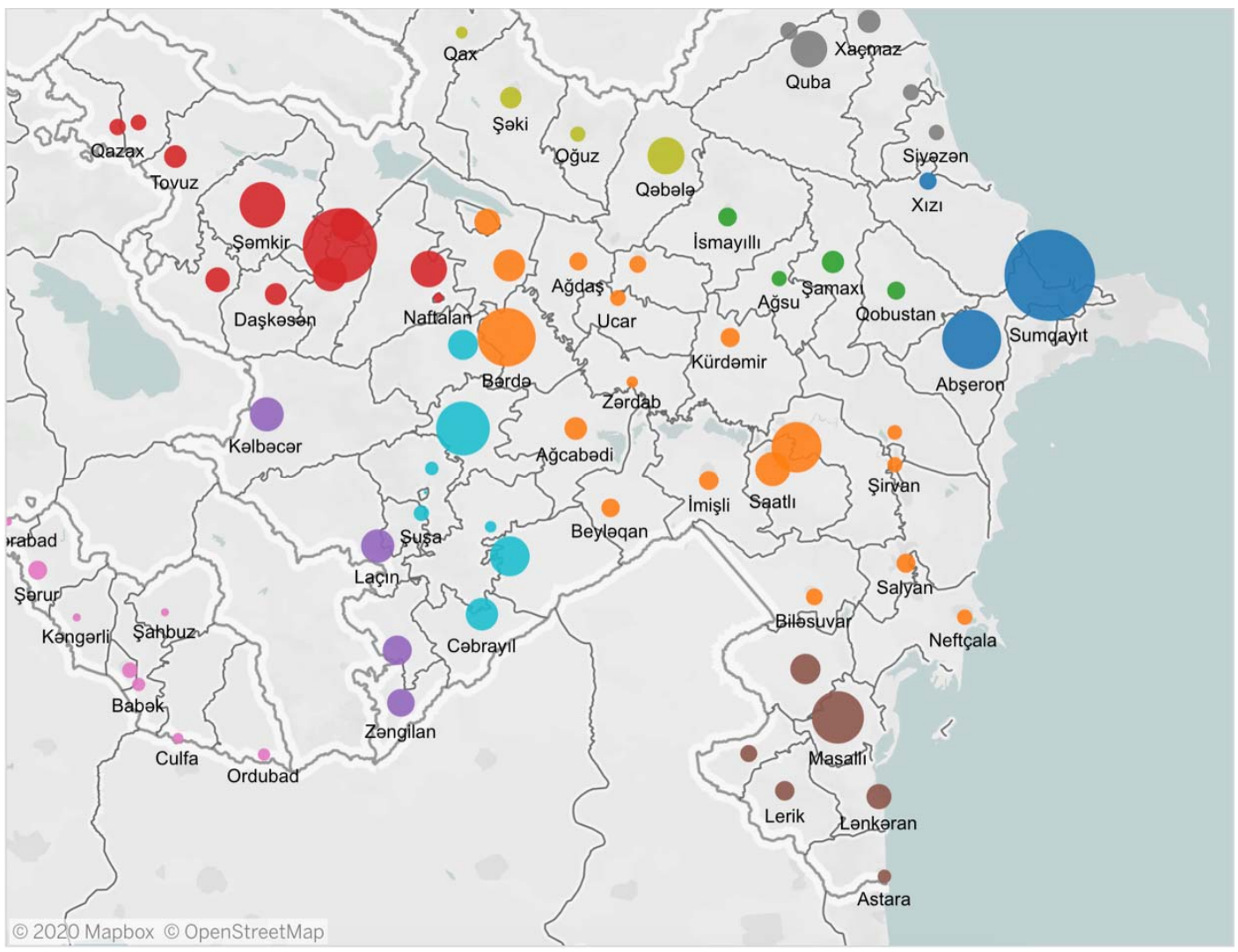

Figure 1. ASAN Service centers 
ASAN Service allows state bodies to directly provide their own services. State agencies providing services are Ministry of Justice, State Committee for Property Affairs, Ministry of Interior, State Migration Service, State Customs Committee, National Archive Department, Ministry of Taxes, State Social Protection Fund, State Service for Mobilization and Conscription, and Functional subsidiary services such as banks, insurance and medical services, legal services and translation services. In addition, modern technologies such as online queuing, e-application functions have been utilized to improve efficiency. The State Agency for Public Service and Social Innovations emphasized that this improvement is a result of sustainable projects implemented in the field of state agencies in Azerbaijan with the establishment of E-government and use of e-services in the framework of "ASAN service", according to the order of the President of the Republic of Azerbaijan in recent years.

During 2013 and 2017, ASAN Service has launched 12 service centers, 2 communal centers, 10 buses served for mobile services, as well as 263 service types, where around $62 \%$ of male and $38 \%$ of female citizens have been served in a country scale (Fig. 2 3).

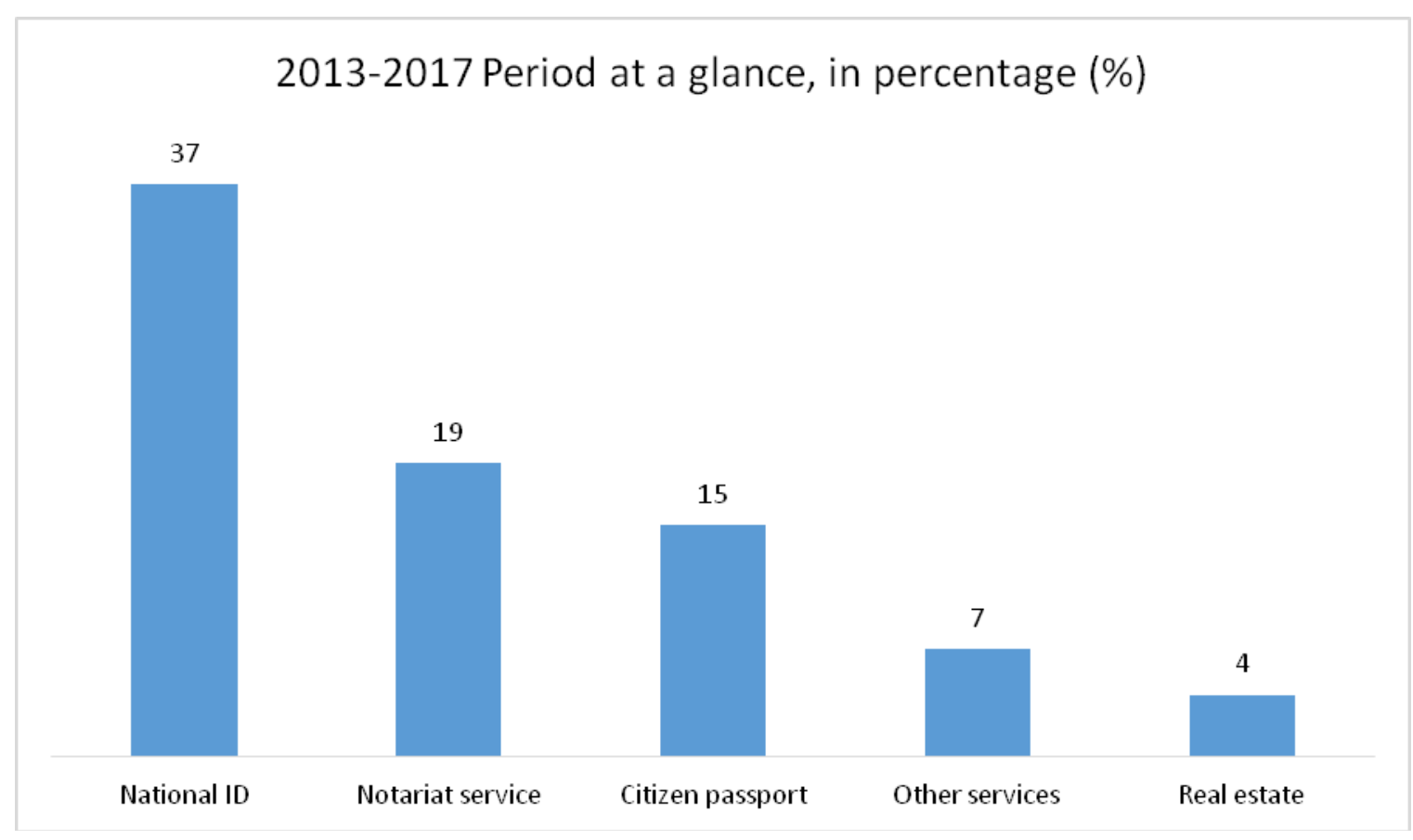

Figure 2. ASAN Service 2013-2017 statistics by services

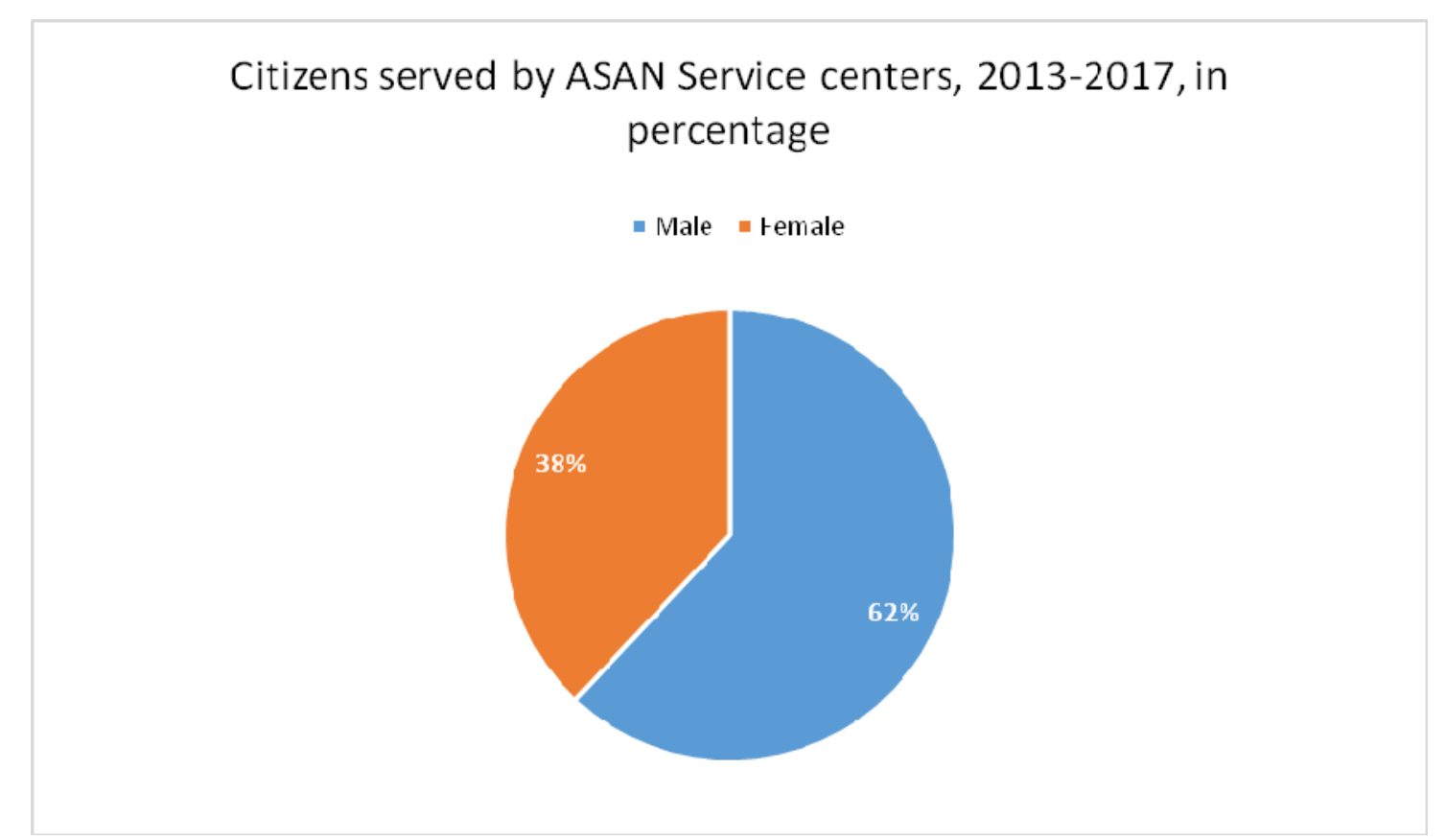

Figure 3. Share of male and females served by SAN Service centers, 2013-2017 
From the facts above, it can be said that ASAN Service is quite successful model and it is estimated that the users of its services will increase exponentially in the coming years, especially in online settings due to the increasing level of internet users over time. To the best knowledge of the researcher, there is still a gap in understanding what factors drive organizational citizenship behavior of those who work in public service sector. In addition, depending on the type of public policy, the role of its effectiveness is also worth to investigate in public service context in Azerbaijan has broadly investigated the factors affecting citizens' behavioral intention to use this government and public e-service.

By addressing this issue, it is worthy to identify the major factors with the inclusion of determinants of organizational citizenship behavior in the context of Azerbaijan. It is important for ASAN Service to keep increasing its service quality in next decades by considering that it is the most transparent public service provider for citizens. Therefore, the findings can help to improve services in other developing and developed countries.

\section{Conclusion}

This chapter is one of the few studies that brings the motivational factors enhance the OCB to the agenda, particularly in the context of Azerbaijan with strong emphasis on ASAN Service model. Since the egovernment practices are successfully implemented in Azerbaijan government, while citizens show great interest in public service through trusted service channel, it is important to understand what motivates public services officials to deliver high-quality services to the citizens, while at the same time it is necessary to predict the forthcoming public service trends and apply it in the country.

From a managerial perspective, one dilemma associated with trying to develop OCB in a workplace is that managers generally are not in a position to require employees to engage in OCBs, since OCBs are understood to be employees' discretionary behaviors. Public managers can enhance employees' OCBs in their organizations by developing group norms or providing appropriate work environments that encourage such behaviors. In addition, it is suggested that task structure (task interdependence) matters in developing employees' decisions to engage in OCB. By developing more interdependent or relational job designs, managers can provide more chances for employees to be engaged in OCBs.

\section{References}

Aggelidid, V. P., \& Chatzoglou, P. D. (2008). Using a modified technology acceptance model in hospitals. Journal of Medical Informatics, 78, 115-126.

Colesca, S. E., \& Dobrica, L. (2008). Adoption and use of e-government services: The case of Romania. Journal of Applied Research and Technology, 6(03).

Jaeger, P. T. (2003). The endless wire: E-Government as global phenomenon. Government Information Quarterly, 20(4), 323-331.

Kim, S., Kim, H. J., \& Lee, H. (2009a). An institutional analysis of an e-Government system for anti-corruption: The case of OPEN. Government Information Quarterly, 26 (1), 42-50.

Kim, S., Kim, H. J., \& Lee, H. (2009b). An institutional analysis of an e-Government system for anti-corruption: The case of OPEN. Government Information Quarterly, 26 (1), 42-50.

Kurfali, M., Arifoglu, A., Tokdemir, G., \& Pacin, Y. (2017). Adoption of e-government services in Turkey. Computers in Human Behavior, 66, 168-178.

OECD (2013) Third Round of Monitoring. Azerbaijan. Monitoring Report. OECD. Retrieved from http://www.oecd.org/corruption/acn/ AZERBAIJANThirdRoundMonitoringReportENG.pdf

Organ, D. W., Podsakoff, P. M., \& MacKenzie, S. B. (2006). Organizational Citizenship Behavior: Its Nature, Antecedents, and Consequences. Thousand Oaks: Sage Publications, Inc.

Organ, D. W. (1997). Organizational Citizenship Behavior: It's Construct Clean-up Time. Human Performance, 10(2), 85-97.

Perry, J. L. (2000). Bringing Society In: Toward a Theory of Public Service Motivation. Journal of Public Administration Research and Theory, 10(2), 471-488.

Rokhman, A. (2011). E-Government adoption in developing countries: the case of Indonesia. Journal of Emerging Trends in Computing and Information Sciences, 2(5), 228-236

Sang, S., Lee, J. D., \& Lee, J. (2009). E-government adoption in ASEAN: The case of Cambodia. Internet Research, 19(5), 517-534.

VISION - The Think-Tank (2015). Moving towards citizens: the "ASAN Service" Model. The Azerbaijani service and assessment network, London.

Отримано: 07.04.2021

Ухвалено до друку: 31.05.2021 Опубліковано: 08.06.2021

Вісник Київського національного університету імені Тараса Шевченка.

Державне управління, 2(14), 10-13.

DOI: https://doi.org/10.17721/2616-9193.2021/14-2/6

Анар Зейналов, асп.

Київський національний університет імені Тараса Шевченка, Київ, Україна e-mail: 2393123@ukr.net

\section{ОРГАНІЗАЦІЙНА ПОВЕДІНКА ГРОМАДЯНСТВА В АЗЕРБАЙДЖАНІ: СПРАВА СЛУЖБИ ASAN}

Службу ASAN - Державне агентство з питань державної служби та соціальних інновацій при Президентові Азербайджанської Республіки - було створено 2012 р., де різні державні органи, а також приватні компанії можуть безпосередньо надавати свої послуги для громадян Азербайджану. Іншими словами, державні органи зобов'язані підвищувати якість своєї роботи, що базується на прозорих і рівних стандартах, винятково на користь громадян.

Однак існує дуже мало праць, що досліджують, які основні рушійні сили спонукають громадян користуватися державними послугами через Службу ASAN. Водночас необхідно розуміти, як формується поведінка організаційного громадянства в цьому контексті. У статmі висвітлено модель надання послуг Службою ASAN в Азербайджані, а також шляхи синхронізації діяльності громадянського суспільства із поточними державними завданнями.

Ключові слова: поведінка організаційного громадянства, державна служба, служба ASAN, Азербайджан. 